\title{
The ASEAN Way to Asia-Pacific Security Community
}

\author{
Aloysius Efraim Leonard \\ Undergraduate Student of International Relations Department at Universitas Katolik Parahyangan \\ aloysiusefraim@gmail.com
}

\begin{abstract}
ASEAN oleh banyak pihak telah dianggap sebagai salah satu dari organisasi regional di dunia yang dapat mempertahankan stabilitas dan keamanan wilayahnya dengan menggunakan nilai - nilai Asia mereka, yang dikenal oleh banyak orang sebagai 'The ASEAN Way'. Dengan menggunakan konsep pembentukan komunitas keamanan oleh Adler dan Barnett, tulisan ini menjelaskan bagaimanakah peran the ASEAN Way dapat membentuk komunitas kemanan Asia - Pasifik, ASEAN Regional Forum (ARF). Proses pembentukan komunitas keamanan dibagi menjadi tiga: adanya faktor internal dan eksternal; kekuatan dan kesamaan persepsi serta hubungan yang terus berlanjut; dan rasa percaya serta identitas bersama. Dalam pembentukannya, ARF didasari oleh keinginan ASEAN untuk menjaga stabilitas di Asia - Pasifik setelah Perang Dingin dan juga mempromosikan nilai - nilai ASEAN ke cakupan yang lebih luas. Kemudian, the ASEAN Way juga sangat berperan sebagai soft power dan persepsi yang menjadi dasar hubungan antarpartisipan ARF. Sehingga, sebuah rasa saling percaya dapat dimiliki oleh partisipan ARF dan juga ARF memiliki identitas bersama yaitu sebagai komunitas keamanan Asia-Pasifik beranggotakan negara besar dan kecil yang membawa prinsip prinsip the ASEAN Way.
\end{abstract}

Keywords: ASEAN, ASEAN Way, ASEAN Regional Forum, security community.

\section{Introduction}

For the past fifty-one years, the countries in Southeast Asia have been living in a peaceful and stable region with the presence of the Association of Southeast Asian Nations (ASEAN). ASEAN was established in August $8^{\text {th }}, 1967$ in Bangkok, Thailand and its existence was marked by the ASEAN Declaration. As written in the declaration, the organization has the aim to accelerate economic growth, promote active collaboration and promote regional peace and stability, among other things. ${ }^{1}$ The organization, by many

\footnotetext{
${ }^{1}$ ASEAN, "The Asean Declaration (Bangkok Declaration) Bangkok, 8 August 1967," ASEAN, https://asean.org/the-asean-declaration-bangkok-declaration-bangkok-8-august-1967/, accessed 22 October 2018. 
scholars, has also been considered successful in using Asian values as its foundation. It is also considered to be the best example of institutional integration in Asia. ${ }^{2}$

In maintaining peace and security in the region, ASEAN is known to have exercised a loose regional security cooperation. ${ }^{3}$ This security cooperation fits their value that is called the 'ASEAN Way', characterized with informality, dialogue, consensus and noninterference. ${ }^{4}$ This 'ASEAN Way' has been the soul of all cooperation happening in the region. The ASEAN security cooperation is manifested in the so-called 'ASEAN Political and Security Community' (APSC), a vision that aims to 'ensure that countries in the region live at peace with one another and with the world in a just, democratic and harmonious environment'. ${ }^{5}$ By agreeing to the APSC, the ASEAN Member States pledge to rely only on peaceful settlements of intra-regional differences. ${ }^{6}$

Realizing its success in maintaining peace and security with the APSC, ASEAN then aimed for a bigger security community in the region of Asia and Pacific, with ASEAN as the center of the cooperation. With this in mind, ASEAN then formed a cooperation called the ASEAN Regional Forum (ARF) in 1994. The ARF is the only security cooperation in government level that has all of the strong states in Asia and Pacific as its participant: the United States of America, People's Republic of China, Japan, Russia and the European Union. $^{7}$ The ARF is bringing the 'ASEAN Way' of settling disputes to a bigger region, one that consists of many great powers in the region. Seeing the facts, this paper then analyzes how the ASEAN Way influenced the establishment of the ARF.

This paper will be divided into three parts. The first part will explain about what is security community and the framework of its establishment. The second one will explain about the ASEAN Way and the third one will explain about the development of the Asia Pacific security community or the ARF, and how the ASEAN Way took part in its establishment.

\footnotetext{
${ }^{2}$ Virginie Briand and Claire Mainguy, "Le processus de régionalisation au sein de l'ASEAN: les enjeux pour les nouveaux membres - Les cas du Vietnam," Mondes en développement, vol. 3, no. 115-116, page 135.

${ }^{3}$ Bob Sugeng Hadiwinata, "Security Thinking in Asia: A Lukewarm Exercise Beyond the Traditionalist View," in Security in a Changing Global Environment: Challenging the Human Security Approach, ed. Christoph Schuck (Baden - Baden: Nomos Verlag, 2011), page 163.

4 ibid.

${ }^{5}$ ASEAN, “ASEAN Political - Security Community,” ASEAN, https://asean.org/asean-political-securitycommunity/, accessed on 22 October 2018.

${ }^{6}$ Ibid.

${ }^{7}$ Kementerian Luar Negeri Republik Indonesia, “ASEAN Regional-Forum (ARF),” Kementerian Luar Negeri Republik Indonesia, https://www.kemlu.go.id/id/kebijakan/kerjasama-regional/Pages/ARF.aspx, accessed 3 November 2018.
} 


\section{Understanding security community}

It is important to first understand the notion of security community. Security community as a concept was first brought by Karl Deutsch and his associates in order to explain the cooperation happening between the North Atlantic region, explaining the security community in the USA, the UK and Germany. ${ }^{8}$ Deutsch argued that security community emerges whenever 'states become integrated to the point that they have a sense of community, which, in turn, creates the assurance that they will settle their differences short of war.' ${ }^{9}$ By joining a security community, a member agrees to not resort to violent means to resolve their disputes with other members. ${ }^{10}$

Security communities are often constructed based on shared interests and identities, rather than perception of a common threat. ${ }^{11}$ According to Acharya, security community is a group of 'like-minded' actors who develop common criteria of inclusion and exclusion. ${ }^{12}$ To explain the founding of a security community, we will refer to the one offered by Adler and Barnett. They write that the framework to build a security community is divided to three tiers: the precipitating conditions; positive, dynamic and reciprocal relationship between the structure; and the emergence of mutual trust and collective identity.

The first tier focuses on the internal and external factors that lead states and other actors to begin their relations. These factors can be technological developments, an external threat, the desire to reduce mutual fear, new social reality, economic transformations, migrations and many other that might affect the security and relations between states and other actors in a region. These factors and conditions will provide the possibility for states to create a cooperation.

In the second tier, 'states and their people have become involved in a series of social interactions that have begun to transform the environment in which they are embedded. ${ }^{13}$ Adler and Barnett distinguished tier into structural and process categories. In the 'structural' category, Adler and Barnett put power and knowledge as the variables. Power is considered to be an important factor for its ability to 'coerce others to maintain collective stance' and as

\footnotetext{
${ }^{8}$ Amitav Acharya, Constructing a Security Community in Southeast Asia: ASEAN and the problem of regional order, (New York: Routledge, 2009), page 17.

${ }^{9}$ Emanuel Adler and Michael Barnett, Security Communities, (Cambridge: Cambridge University Press, 1998), page 3 .

${ }^{10}$ Ralf Emmers, "Security Cooperation in the Asia-Pacific: Evolution of Concept and Practices," in Asia-Pacific Security Cooperation, ed. See Seng Tan and Amitav Acharya, (New York: M.E. Sharpe, 2004), page 8.

${ }^{11}$ Amitav Acharya, Constructing a Security Community in Southeast Asia: ASEAN and the problem of regional order, (New York: Routledge, 2009), page 22.

${ }^{12}$ Ibid.

${ }^{13}$ Emanuel Adler and Michael Barnett, Security Communities, (Cambridge: Cambridge University Press, 1998), page 39 .
} 
'the authority to determine shared meaning'. ${ }^{14}$ While knowledge here is stressed on the shared meanings and understandings, that can take form in ideology and ideas. In the 'process' category, Adler and Barnett put transactions, organizations and social learning as the variables. A transaction is defined as a 'bounded communication between one actor and another'. ${ }^{15}$ Institutions and organizations are also considered to contribute directly towards the formation of a security community as they help the development of trust. Under these variables, collective identity and mutual trust can form.

In the last tier, mutual trust and collective identities between the states will emerge. Trust and identity is considered to be the most important factor in building a security community. Identity defines 'who we are' and 'how we differ from others'. ${ }^{16}$ This collective identity will emerge after the act of transaction. So, it is important to consider the quality and the quantity of transactions done by states.

\section{The ASEAN Way of Securing the Region}

The ASEAN Way is considered to be a 'by-product of cultural similarities among the ASEAN societies. ${ }^{17}$ It has the characteristics of being informal, and also have the practice of consensus building. The process of consensus building, in the ASEAN context, derived from the style of decision making in a Javanese village society, in a process called musyawarah (consultation) and mufakat (consensus). ${ }^{18}$

It is written in the ASEAN Charter that the ASEAN Member States should act in accordance to the principle that they have agreed upon. They will have to renounce the use of force, rely on peaceful settlement of disputes and not intervene in the internal affairs of other ASEAN Member States. ${ }^{19}$ These principles are the ones that build the so-called 'ASEAN Way'.

The 'ASEAN Way' of dispute settlements has been used even before ASEAN adopted their charter in 2007. The first time we can see how ASEAN settle disputes between its member states is through the Treaty of Amity and Cooperation or the TAC. The TAC was adopted in 1976 and it uphold the principles of mutual respect for the independence, sovereignty; non-interference; settlements of disputes in peaceful means and renunciation of

\footnotetext{
${ }^{14}$ ibid.

15 ibid., page 41.

${ }^{16}$ Amitav Acharya, Constructing a Security Community in Southeast Asia: ASEAN and the problem of regional order, (New York: Routledge, 2009), page 28.

${ }^{17}$ Ibid., page 78.

18 Ibid., 82.

${ }^{19}$ ASEAN, The ASEAN Charter, (Jakarta: ASEAN Secretariat, 2008), page 6.
} 
threat and use of force. ${ }^{20}$ Since then as the principle written in the TAC are being used frequently by the ASEAN Member States, when they are formulating the ASEAN Charter, those principles are then adopted in the charter as the main principles of interstate relations in ASEAN.

The most prominent example of how successful the ASEAN Way was in settling dispute in the Southeast Asian region was during the Vietnam-Cambodian War. In the late 1970s, Vietnam was the one who freed the Cambodians from a murderous Khmer Rouge that killed almost 2 millions Cambodians. ${ }^{21}$ However, even though the Vietnamese troops liberated Cambodians from the regime of Pol Plot, its acts were considered unacceptable because they were changing another country's regime by force. ${ }^{22}$ ASEAN back then supported the Khmer Rouge's government as the rightful government of Cambodia but refused to deliver weapons to them. ${ }^{23}$ Other than that, during the time, it was feared that Vietnam, that was backed by the Soviet, would spread the its backer at the time. To settle the problem, ASEAN led the dispute settlement through diplomacy in the UN, and finally the problem reached settlement in 1991 after several series of conferences were done.

The ASEAN Way has been successful in keeping the region stable and peaceful. The norms of the ASEAN Way, as Noordin Sopiee stated in Busse, are 'the principle of seeking agreement and harmony, the principle of sensitivity, politeness, non-confrontation and agreeability. ${ }^{24}$ Busse also stated that another success that has been achieved by ASEAN through the ASEAN Way is the fact that war among the founding members of ASEAN became 'unthinkable' as being part of ASEAN has become a 'part of their identity'. ${ }^{25}$

\section{The ASEAN Way to Asia-Pacific Security Community?}

In building the Asia - Pacific security community, ASEAN has created the ASEAN Regional Forum (ARF). This security community has participants that spread all across Asia and Pacific, including Australia, Bangladesh, ASEAN Member States, Republic of Korea, European Union, New Zealand, DPR Korea, Canada, China, Russia, Japan and the United

\footnotetext{
${ }^{20}$ ASEAN, "Treaty of Amity and Cooperation in Southeast Asia Indonesia, 24 February 1976," ASEAN, https://asean.org/treaty-amity-cooperation-southeast-asia-indonesia-24-february-1976/, accessed 2 November 2018.

${ }^{21}$ Kevin Doyle, "Vietnam's forgotten Cambodian War,” BBC, https://www.bbc.com/news/world-asia-29106034, accessed 3 November 2018.

${ }^{22}$ Rudolfo C. Severino, ASEAN, (Singapore: Institute of Southeast Asian Studies, 2008), page 18.

${ }^{23}$ Nikolas Busse, "Constructivism and Southeast Asian security," The Pacific Review 12, no 1 (1999): 50.

${ }^{24}$ Ibid., page 47.

${ }^{25}$ Ibid., page 54.
} 
States, to name a few. ${ }^{26}$ As stated during the $27^{\text {th }}$ ASEAN Ministerial Meeting in 1994, ASEAN needs to 'work with its ARF partners bring about a more predictable and constructive pattern of relations in the Asia-Pacific. ${ }^{27}$ As seen on the ARF Vision Statement, the ARF is seen as the 'central pillar in the evolving regional security architecture'. ${ }^{28}$ It is also written that ASEAN will play as the 'primary driving force in the ARF process' and all of the member of the ARF will recognize the importance of 'fully adhering to the purposes and principles of the TAC'. 29

Seeing this, we can try to analyze the establishment of ARF with Adler's framework for security community establishment. Then we can find out how the ASEAN Way influences the establishment of the ARF.

To understand the internal and external factors of how the ARF was established, we must first look upon what happened during the time frame of the establishment of ARF. The ARF was established in 1994, at the end of Cold War. In the early 1990s, during the first years of the post-Cold War era, new security issues in Asia emerges: US' involvement in the region, territorial dispute in the South China Sea, instability in the Korea Peninsula, and gradual expansion of ASEAN. ${ }^{30}$ ASEAN also sees that China's assertiveness over the South China Sea dispute is growing. ${ }^{31}$ This leads to another motivation for ASEAN to establish the ARF, which is to 'engage Beijing in a comprehensive fashion in a stable regional international system.${ }^{32}$ Another factor or motivation of the establishment of the ARF came from ASEAN itself, that wanted to promote their way in dealing with regional security issues. ${ }^{33}$ Those were the factors, internal and external, that leads ASEAN to establish a security community in Asia-Pacific region.

The second tier of the establishment of a security community in Asia-Pacific is arguably the most important one. Adler and Barnett stated that this tier is made up from two categories: structural and process. For the structural category, the 'power' and the

\footnotetext{
${ }^{26}$ ASEAN Regional Forum, “About the ASEAN Regional Forum,” ASEAN Regional Forum, http://aseanregionalforum.asean.org/about.html, accessed 3 November 2018.

${ }^{27}$ Ibid.

${ }^{28}$ ASEAN Regional Forum, “ASEAN Regional Forum Vision Statement," Ministry of Foreign Affairs Japan, https://www.mofa.go.jp/region/asia-paci/asean/conference/arf/state0907-2.pdf, accessed 3 November 2018.

${ }^{29}$ Ibid.

${ }^{30}$ Jürgen Haacke and Noel M. Morada, Cooperative Security in the Asia-Pacific: The ASEAN Regional Forum,

(New York: Routledge, 2010), page 14.

${ }^{31}$ Ibid., page 15.

${ }^{32}$ Ralf Emmers, Cooperative Security and the Balance of Power in ASEAN and the ARF, (New York:

RoutledgeCurzon, 2003), page 31.

${ }_{33}$ Jürgen Haacke and Noel M. Morada, Cooperative Security in the Asia-Pacific: The ASEAN Regional Forum, (New York: Routledge, 2010), page 16.
} 
'knowledge' that build ARF is the ASEAN Way. While the ASEAN Way of informality, non-interference and peaceful dispute settlements can definitely be considered as the common knowledge between the ARF countries, the ASEAN Way can be considered as ASEAN's soft power. The ASEAN Way has been the basic principle of relations between ARF participants. With the ASEAN Way, ASEAN managed to keep the great powers stay as the participant to the forum. ASEAN is also successful in promoting this principle, especially as non-ASEAN participants of the ARF have been endorsing ASEAN's TAC. ${ }^{34}$ Under the process category, we can see that by using the ASEAN Way, participants of the ARF are now having relations through consultation and consensus and in peaceful means. An example is the South China Sea problem. The ARF plays as a supporting role to the dispute, in which ASEAN Member States and China are resolving their disputes through consultation and in informal meetings, for example in the Jakarta Informal Meetings and China-ASEAN Senior Official Consultations. ${ }^{35}$

Through a very peaceful 'transaction' and based on the same knowledge and power that influenced them, the ARF participants then finally find their mutual trust and common identity. ASEAN through ARF has been able to institutionalized multilateral security dialogue in the Asia-Pacific. ${ }^{36}$ ASEAN has also been able to create a forum in which major world powers gather together and have trusts to each other based on the ASEAN Way or principle: the US, EU, China, Russia. It has also gained a new common identity: the ARF is a forum that can gather different states in Asia and Pacific to discuss about security cooperation and confidence building by using the ASEAN principle.

\section{Conclusion}

In securing the Southeast Asia region, the establishment of ASEAN has been considered to be successful. ASEAN brought their own mode of securing the region with the ASEAN Way of security that consists of the principle of informality, consensus, noninterference and peaceful settlement of dispute. This has been proved to be successful during the time of the Vietnam invasion to Cambodia. Seeing that, ASEAN has decided to establish a bigger security community in the Asia-Pacific region, known as the ASEAN Regional Forum (ARF). It can be seen that the ARF was established by ASEAN because of several

\footnotetext{
34 Ibid.

${ }^{35}$ Dirk Storthmann, Das ASEAN Regional Forum: Chancen und Grenzen regionaler Sicherheitkooperation in Ostasien, (Dieblich: Springer VS, 2012) page 268.

${ }^{36}$ Ralf Emmers, Cooperative Security and the Balance of Power in ASEAN and the ARF, (New York:

RoutledgeCurzon, 2003), page 34.
} 
external and internal motivations - to create stability in the Asia-Pacific region after Cold War and to promote their own way of settling dispute, the ASEAN Way. In the development and establishment of the ARF, the ASEAN Way has been the common knowledge and the soft power that governs the relations between the ARF participants. Eventually, the relations between the participants lead to a mutual trust between them-including great powers such as the US, China, Russia and EU-and also giving them a common identity, which is a forum that gathers heterogenous participants in Asia-Pacific, bonded together by the ASEAN Way. 


\section{Bibliography}

Acharya, Amitav. Constructing a Security Community in Southeast Asia: ASEAN and the problem of regional order. New York: Routledge, 2009.

Adler, Emanuel and Michael Barnett. Security Communities. Cambridge: Cambridge University Press, 1998.

ASEAN Regional Forum, “About the ASEAN Regional Forum,” ASEAN Regional Forum, http://aseanregionalforum.asean.org/about.html, accessed 3 November 2018.

ASEAN Regional Forum, “ASEAN Regional Forum Vision Statement,” Ministry of Foreign Affairs Japan, https://www.mofa.go.jp/region/asia-paci/asean/conference/arf/state09072.pdf, accessed 3 November 2018.

ASEAN. "The Asean Declaration (Bangkok Declaration) Bangkok, 8 August 1967.” ASEAN. https://asean.org/the-asean-declaration-bangkok-declaration-bangkok-8-august-1967/. Accessed 22 October 2018.

ASEAN. "ASEAN Political - Security Community." ASEAN. https://asean.org/aseanpolitical-security-community/. Accessed on 22 October 2018.

ASEAN. "Treaty of Amity and Cooperation in Southeast Asia Indonesia, 24 February 1976." ASEAN. https://asean.org/treaty-amity-cooperation-southeast-asia-indonesia-24february-1976/. Accessed 2 November 2018.

ASEAN. The ASEAN Charter. Jakarta: ASEAN Secretariat, 2008.

Briand, Virginie and Claire Mainguy. 'Le processus de régionalisation au sein de l'ASEAN: les enjeux pour les nouveaux membres - Les cas du Vietnam.” Mondes en développement. vol. 3, no. 115-116 (2001): 135 - 150.

Busse, Nikolas. "Constructivism and Southeast Asian security." The Pacific Review vol 12, no 1 (1999): 39 - 60.

Doyle, Kevin. "Vietnam's forgotten Cambodian War." $B B C$, https://www.bbc.com/news/world-asia-29106034, accessed 3 November 2018.

Emmers, Ralf. "Security Cooperation in the Asia-Pacific: Evolution of Concept and Practices." In Asia-Pacific Security Cooperation. Edited by See Seng Tan and Amitav Acharya, page 3 - 18. New York: M.E. Sharpe, 2004.

Emmers, Ralf. Cooperative Security and the Balance of Power in ASEAN and the ARF. New York: RoutledgeCurzon, 2003.

Haacke, Jürgen and Noel M. Morada. Cooperative Security in the Asia-Pacific: The ASEAN Regional Forum. New York: Routledge, 2010. 
Hadiwinata, Bob Sugeng. "Security Thinking in Asia: A Lukewarm Exercise Beyond the Traditionalist View." In Security in a Changing Global Environment: Challenging the Human Security Approach. Edited by Christoph Schuck, page 153 - 175. Baden Baden: Nomos Verlag, 2011.

Kementerian Luar Negeri Republik Indonesia. “ASEAN Regional-Forum (ARF).” Kementerian Luar Negeri Republik Indonesia.

https://www.kemlu.go.id/id/kebijakan/kerjasama-regional/Pages/ARF.aspx. Accessed on 3 November 2018.

Severino, Rudolfo C. ASEAN. Singapore: Institute of Southeast Asian Studies, 2008.

Storthmann, Dirk. Das ASEAN Regional Forum: Chancen und Grenzen regionaler Sicherheitkooperation in Ostasien. Dieblich: Springer VS, 2012. 